\title{
KEMANDIRIAN BELAJAR MAHASISWA PENJAS MENGGUNAKAN MEDIA GOOGLE CLASSROOM MELALUI HYBRID LEARNING PADA PEMBELAJARAN PROFESI PENDIDIKAN DI MASA PANDEMI COVID-19
}

\author{
Azizatul Banat ${ }^{1}$, Martiani $^{2}$ \\ ${ }^{1,2}$ Universitas Dehasen Bengkulu

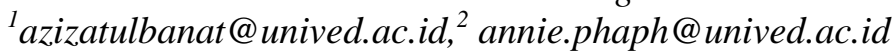

\begin{abstract}
Abstrak: Penelitian ini bertujuan untuk mengetahui kemandirian belajar mahasiswa Penjas menggunakan media google classroom melalui hybrid learning pada pembelajaran profesi pendidikan di masa pandemi COVID-19. Populasi dalam penelitian ini adalah mahasiswa Pendidikan Jasmani Fakultas Keguruan dan Ilmu Pendidikan Universitas Dehasen Bengkulu Semester II Tahun Akademik 2019/2020. Pengambilan sampel menggunakan random sampling dengan sampel penelitian berjumlah 80 orang merupakan mahasiswa A1 dan A2 Program Studi Pendidikan Jasmani Fakultas Keguruan dan Ilmu Pendidikan Universitas Dehasen Bengkulu. Teknik pengumpulan data menggunakan triangulasi menggunakan angket, wawancara dan pengamatan. Hasil penelitian menunjukkan bahwa rata-rata tingkat kemandirian belajar mahasiswa menggunakan media Google Classroom melalui Hybrid Learning pada pembelajaran profesi pendidikan di masa pandemi Covid-19 ini adalah sangat kuat berada pada nilai rata-rata indikator: percaya diri (81,82), disiplin (83,5), inisiatif (81,44), Tanggung Jawab (85,94), Motivasi (85,25), sehingga rata-rata indikator kemandirian belajar adalah 83,59. Dari hasil tersebut dapat diinterpretasikan berdasarkan rentang skala kriteria interpretasi skor tingkat capaian responden, maka interpretasi kemandirian belajar mahasiswa Penjas menggunakan Media Google Classroom Melalui Hybrid Learning pada Pembelajaran Profesi Pendidikan di masa pandemi Covid 19 adalah sangat kuat.
\end{abstract}

Kata Kunci: kemandirian belajar, google classroom, blended learning, percaya diri, disiplin, inisiatif, tanggung jawab, motivasi.

\begin{abstract}
This study aims to determine independent learning of Physical Education students use Google Classroom media through hybrid learning in the Educational Profession learning during the COVID-19 pandemic. The population in this study were students of Physical Education, Faculty of Teacher Training and Education, The University of Dehasen Bengkulu, Semester II of the Academic Year 2019/2020. Sampling techniques using random sampling with a research sample of 80 students of A1 and A2 classes of the Physical Education Study Program of the Teaching Training and Education Faculty of Dehasen Bengkulu University. Data collection techniques using triangulation: questionnaires, interviews and observations. The results showed that the average level of student learning independence using google classroom media through hybrid learning in of the educational profession learning during the COVID-19 pandemic was very strong at the average value of indicators: self-confidence (81.82), discipline ( 83.5), initiative (81.44), responsibility (85.94), motivation (85.25), then the average indicator of independent learning is 83.59. From these results it can be interpreted based on the scale range of the criteria for interpretation of the score of the respondent's level of achievement, then the interpretation of learning independence of Physical Education students using Google Classroom Media through Hybrid Learning in Educational Professional Learning during the Covid 19 pandemic is very strong.
\end{abstract}

Keywords: independent learning, google classroom, hybrid learning, confidence, discipline, initiative, responsibility, motivation.

\section{PENDAHULUAN}

Mewabahnya Pandemi COVID-19 di Indonesia, menempatkan cara belajar dan mengajar dalam dunia pendidikan juga mengalami perubahan. Ketika dihadapkan pada situasi yang memaksa kita harus belajar lebih giat dan beradaptasi menggunakan berbagai media dalam pembelajaran namun setidaknya dapat tetap melangsungkan proses belajar mengajar yang semestinya serta memaksimalkan proses dimanapun dan kapanpun. Hal yang paling dibutuhkan dalam proses belajar mengajar pada masa Pandemi COVID-19 adalah kemandirian dalam belajar, meskipun prosedur keamanan tingkat tinggi untuk selalu menjaga jarak dan kesehatan harus selalu diutamakan, namun belajar mandiri tetap harus dimaksimalkan. 
Pembelajaran pada mahasiswa di perguruan tinggi seyogyanya bukan suatu permasalahan untuk memaksa mahasiswa belajar mandiri, namun bagi mahasiswa semester awal, bukanlah hal mudah untuk beradaptasi dari bangku sekolah SMA hingga memasuki bangku perkuliahan, tahun pertama perkuliahan pada umumnya masih dianggap masa penyesuaian metode dan cara belajar mandiri, begitu pula bagi mahasiswa Pendidikan Jasmani yang terbiasa dengan sistem pembelajaran praktek lapangan atau teori secara tatap muka serta jarang menggunakan teknologi komputerisasi sebagai bagian atau rutinitas pembelajaran, namun Pandemi COVID-19 yang mewabah tepat pada pertengahan semester perkuliahan di Indonesia, tepatnya di daerah Bengkulu, menuntut dosen pengajar dan mahasiswa harus berupaya keras tetap melaksanakan pembelajaran dengan keterbatasan ruang gerak yang ada. Hal ini pula menuntut kemandirian belajar mahasiswa dan memaksimalkan upaya pengajar dalam mempelajari dan mempersiapkan media pembelajaran yang terjangkau dan mudah digunakan secara umum bagi mahasiswa.

$$
\text { Belajar mandiri sebagaimana }
$$

dikemukakan Yamin dalam Sudarwo, dkk (2018:69) merupakan cara belajar aktif dan partisipatif untuk mengembangkan diri masingmasing individu yang tidak terikat dengan kehadiran pembelajar dalam suatu pertemuan tatap muka kelas atau kehadiran teman belajar lain. Kemandirian belajar dapat diartikan sebagai suatu sikap yang memungkikan seseorang melakukan hal dan tindakan secara bebas baik atas dorongan dari diri sendiri maupun untuk kebutuhan diri sendiri tanpa bantuan pihak lainnya, maupun bertindak dan berpikir kreatif dan original (asli), inisiatif dan mampu mempengaruhi lingkungan, memiliki rasa percaya diri dan memperoleh suatu kepuasan yang dihasilkan dari usaha yang dilakukannya (Masrun, 1986:8). Sependapat dengan Masrun, Haris Mujiman (2008) menjelaskan bahwa kemandirian belajar merupakan kegiatan belajar secara aktif, didorong oleh niat maupun motif untuk menguasai kompetensi dalam mengatasi/memecahkan masalah, yang dibangun dengan pengetahuan serta kompetensi yang dimiliki. Pendapat lainnya tentang kemandirian belajar dijelaskan oleh Stephen Brookfield (2000;130-133) bahwa kesadaran diri yang digerakkan oleh diri sendiri serta memiliki kemampuan belajar untuk mewujudkan/mencapai tujuan tersebut. Selanjurnya, Anita Lie dalam Suryaningsih (2017:3) menjelaskan bahwa seseorang yang telah memiliki kemandirian belajar yang baik akan konsisten, bersemangat belajar dan giat belajar dimanapun dan kapanpun, sebab dalam dirinya telah mengalir kesadaran kebutuhan belajar, disiplin, mempunyai inisiatif, kontrol diri dan tanggung jawab serta percaya diri untuk mencapai kompetensi. Dari beberapa pendapat diatas, dapat disimpulkan indikator-indikator kemandirian belajar antara lain: percaya diri, disiplin, inisiatif, tanggung jawab dan motivasi.

Berdasarkan indikator kemandirian belajar tersebut diatas, maka perlu untuk disusun menjadi rincian deskriptor dan dinilai berdasarkan sistem pembelajaran yang digunakan, perubahan sistem pembelajaran yang awalnya dengan sistem tatap muka pada masa normal hingga berubah memasuki masa pandemi ini, maka peneliti menerapkan Hybrid Learning atau Blended Learning pada mahasiswa. Istilah hybrid learning atau sering pula disebut dengan blended learning merupakan penggabungan pembelajaran tatap muka dengan pembelajara online. Bersin (2004: 56) menjelaskan pengertian blended learning: the combination of different training " media" (technologies, activities, and types of events) to create an optimum training program for a specific audience. The term "blended" means that traditional instructir-led training is being supplemented with other electronic formats. In the context of this book, blended learning programs use many different forms of $e$ learning, perhaps complemented with instructor-led training and other live formats. Dapat disimpulkan dari pendapat ini bahwa hybrid learning atau blended learning merupakan perpaduan pembelajaran tradisional dan elektronik sebagai pembelajaran berlandaskan web, streaming video, komunikasi audio synchronous dan asynchronous melalui pembelajaran bersifat tradisional atau tatap muka.

Hybrid Learning ini diterapkan oleh peneliti sejak pertengahan semester hingga akhir semester untuk dapat meneruskan proses belajar mengajar, adapun media yang digunakan adalah media google classroom yang dapat diakses melalui laptop ataupun android, cukup mudah dipelajari serta merupakan aplikasi yang cukup ringan untuk menjangkau mahasiswamahasiswa meski dengan berbagai keterbatasan 
jaringan internet dari rumah. Meskipun dengan keadaan tanpa persiapan yang maksimal, namun peneliti berupaya mempelajari dari berbagai rujukan penelitian terdahulu untuk dapat meneruskan proses belajar mengajar dengan maksimal di masa pandemi COVID-19. Beberapa penelitian tentang blended learning digunakan peneliti sebagai rujukan antara lain: Penelitian I Ketut Widiara (2018) berjudul "Blended Learning sebagai Alternatif Pembelajaran di Era Digital" menjelaskan bahwa blended learning merupakan salah satu pilihan ketika belajar tidak cukup hanya dengan tatap muka, disamping itu pula blended learning merupakan salah satu alternatif strategi belajar mengajar ditengah pesatnya arus informasi dan komunikasi di berbagai lapisan masyarakat maka pilihan ini cukup tetap untuk memadukan pembelajaran tatap mukan dan online. Penambahan inovasi yang tepat dapat membangkan kemandirian dan percaya diri siswa dalam mengeksplorasi sumber belajar tidak hanya dari guru saja. Penelitian selanjutnya dilakukan oleh Sulihin B. Sjukur (2013) berjudul “ Pengaruh Blended Learning Terhadap Motivasi Belajar dan Hasil Belajar Siswa Tingkat SMK", Hasil penelitian Sulihin B. Sjukur menunjukkan bahwa terdapat perbedaan motivasi belajar siswa menggunakan blended learning dibandingkan siswa yang diajarkan pembelajaran konvensional, kemudian ada peningkatan motivasi siswa akibat penerapan blended learning.

Berdasarkan permasalahan dan kondisi diatas, peneliti tertarik untuk melakukan pengkajian lebih mendalam mengenai Kemandirian Belajar Mahasiswa Penjas Menggunakan Media Google Classroom Melalui Hybrid Learning Pada Pembelajaran Profesi Pendidikan di Masa Pandemi COVID19.

\section{METODE}

Penelitian ini adalah penelitian deskriptif dengan data penelitian menggunakan data kualitatif. Penelitian ini dilakukan di Program Studi Pendidikan Jasmani FKIP Universitas Dehasen Bengkulu. Populasi berjumlah lebih kurang 120 orang (Kelas A1, A2, A3). Sampel digunakan adalah mahasiswa Pendidikan Jasmani semester II Tahun Akademik 2019/2020. Pengambilan sampel digunakan dengan cara random sampling yaitu kelas A1 dan A2 berjumlah 80 orang. Teknik pengumpulan data menggunakan teknik triangulasi teori dengan expert judgement, kuesioner dan wawancara serta pengamatan. Tim ahli (expert) yang membantu penelitian ini terdiri dari: 2 orang ahli, 1 orang di bidang bahasa ( Ibu Mariska Febrianti, S.S., M.Pd./ Dosen Bahasa di UNIVED Bengkulu) untuk menilai bahasa instrumen angket dan wawancara tidak terstruktur, serta 1 orang ahli di bidang pendidikan (Bapak Edi Susanto, M.Pd./Dosen di Program Studi Pendidikan Komputer FKIP Universitas Dehasen Bengkulu).

Pelaksanaan penelitian dilaksanakan selama 2 bulan (setengah semester) dengan jumlah pertemuan belajar sebanyak 6 kali pertemuan belajar (3 kali pembelajaran tatap muka dan 3 kali pembelajaran online), dan 2 kali tes (post-test dan pre-test) untuk melihat kestabilan nilai belajar. Selama pembelajaran tatap muka tetap berbantuan media online Google Classroom untuk mengarahkan penugasan dan pembelajaran). Dari pelaksanaan pembelajaran tersebut, dilakukan pengamatan pembelajaran oleh peneliti dan tim ahli dan di akhir pembelajaran mahasiswa diberikan angket untuk menilai tingkat kemandirian belajar mahasiswa, dan dilakukan wawancara pada beberapa mahasiswa yang dipilih acak sebanyak 10 orang. Adapun instrumen angket kemandirian belajar menggunakan 5 alternatif jawaban: Selalu (SL), Sering (SR), KadangKadang (KK), Jarang (JR), Tidak Pernah (TP), 5 alternatif ini diberikan nilai tertinggi pada angka 5 untuk SL sampai dengan nilai terendah pada angka 1 untuk TP. Berikut ini merupakan kisi-kisi instrumen kemandirian belajar siswa untuk butir yang telah divalidasi oleh tim expert judgement:

Tabel 1. Kisi-kisi instrumen kemandirian belajar siswa

\begin{tabular}{lccc}
\hline \multirow{2}{*}{ Indikator } & \multicolumn{2}{c}{$\begin{array}{c}\text { Nomor butir } \\
\text { pernyataan }\end{array}$} & \multirow{2}{*}{ Jlh } \\
\cline { 2 - 3 } & Positif & Negatif & \\
\hline Percaya & $3,5,6,7$ & $1,2,4$ & 7 \\
Diri & & & \\
\hline Disiplin & $8,9,10$ & $38,39,40$ & 3 \\
\hline Inisiatif & $\begin{array}{c}11,12,14,15, \\
\text { 16,17 }\end{array}$ & 13,18 & 8 \\
\hline Tanggung & $19,20,22,23$ & $21,24,25$, & 8 \\
Jawab & \multicolumn{3}{c}{26} \\
\hline Motivasi & $27,28,30,31$, & $29,34,36$ & 11 \\
& $32,33,35,37$ \\
Jumlah & 25 & 15 & 40 \\
\hline
\end{tabular}


Berdasarkan tabel diatas, terdapat 40 butir pernyataan instrumen yang disusun namun setelah dilakukan validasi oleh expert judgement maka diperoleh 37 butir pernyataan instrumen yang layak dan valid digunakan sebagai instrumen angket. Hasil penilaian angket kemudian dirata-ratakan dan diterjemahkan berdasarkan kriteria interpretasi skor untuk tingkat capaian responden.

\section{HASIL DAN PEMBAHASAN}

Berdasarkan data kemandirian belajar mahasiswa yang diperoleh dari hasil angket kemandirian belajar yang diberikan kepada mahasiswa setelah dilakukan pembelajaran menggunakan media Google Classroom melalui Hybrid Learning adalah sebagai berikut:

Tabel 2. Tabel Data Angket Kemandirian Belajar Mahasiswa

\begin{tabular}{llc}
\hline No & $\begin{array}{c}\text { Indikator Kemandirian } \\
\text { Belajar }\end{array}$ & $\begin{array}{c}\text { Rata-Rata } \\
\text { Nilai }\end{array}$ \\
\hline 1. & Percaya Diri & 81,82 \\
\hline 2. & Disiplin & 83,5 \\
\hline 3. & Inisiatif & 81,44 \\
\hline 4. & Tanggung Jawab & 85,94 \\
\hline 5. & Motivasi & 85,25 \\
\hline & Rata-rata keseluruhan & 83,59 \\
\hline
\end{tabular}

Dari data diatas dapat digambarkan melalui grafik di bawah ini guna memperjelas tingkatan rata-rata nilai:

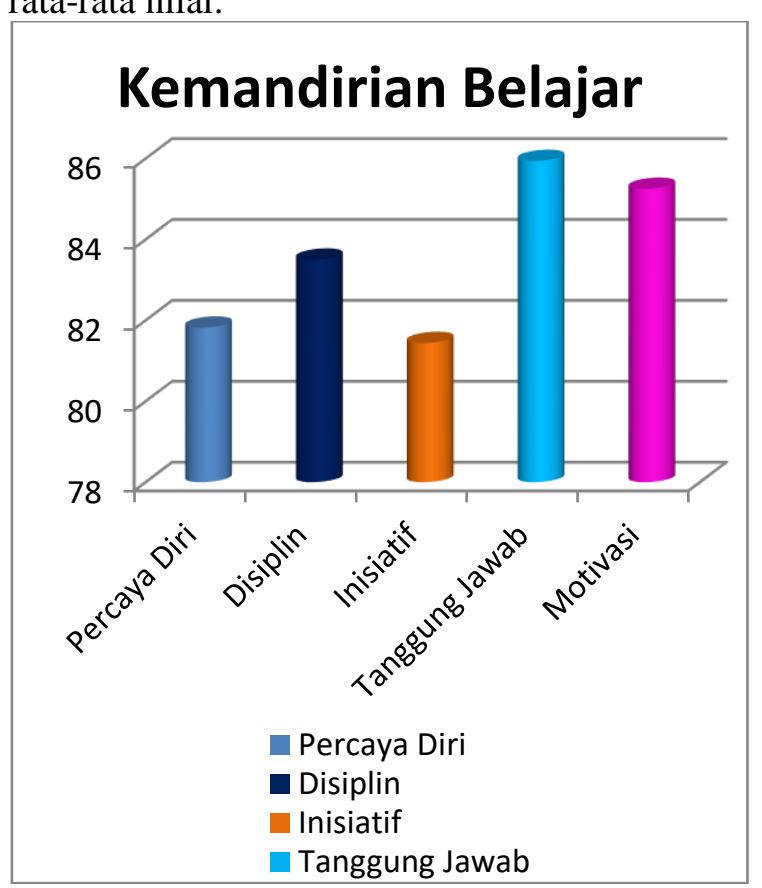

Gambar 1. Kemandirian Belajar Mahasiswa Berdasarkan Indikator
Dari data nilai diatas akan diterjemahkan menggunakan rentang data menurut Ridwan (2006:88) menjelaskan tentang kriteria interpretasi skor untuk Tingkat Capaian Responden adalah sebagai berikut:

Tabel 3. Rentang Skala Tingkat Capaian Responden

\begin{tabular}{ccc}
\hline No & Angka & Keterangan \\
\hline $\mathbf{1}$ & $00 \%-20 \%$ & Sangat lemah \\
\hline $\mathbf{2}$ & $21 \%-40 \%$ & Lemah \\
\hline $\mathbf{3}$ & $41 \%-60 \%$ & Cukup \\
\hline $\mathbf{4}$ & $61 \%-80 \%$ & Kuat \\
\hline $\mathbf{5}$ & $81 \%-100 \%$ & Sangat kuat \\
\hline
\end{tabular}

Berdasarkan rata - rata nilai kemandirian belajar, rata-rata nilai pada bagian indikator percaya diri adalah 81,82 berada pada interpretasi rentang skala sangat kuat. Berdasarkan hasil wawancara dan pengamatan pada mahasiswa diperoleh informasi bahwa tingkat percaya diri mahasiswa untuk belajar menggunakan teknologi cukup teruji, mahasiswa yang terkadang merasa tidak percaya diri untuk menunjukkan kemampuan pada pertemuan tatap muka, tetap memperoleh kesempatan untuk menunjukkan kemampuan melalui Google Classroom seperti dengan cara aktif menuliskan komentar pertanyaan maupun menanggapi jawaban pada kolom komentar classroom, ataupun ketika mengerjakan tugas berbentuk rekaman video yang diunggah pada laman google classroom sebab mereka memiliki keleluasaan waktu dan kemudahan interaksi dalam dunia maya serta leluasa untuk berpendapat melalui kolom komentar. Hal ini sejalan dengan pendapat Bender \& Waller, 2014: 37) Google Classroom sesungguhnya dirancang untuk mempermudah interaksi guru dan siswa dalam dunia maya. Aplikasi ini memberikan kesempatan kepada para guru untuk mengeksplorasi gagasan keilmuan yang dimiliki begitupun memiliki keleluasaan waktu berbagi ilmu dan tugas serta membuka ruang tanya jawab dalam classroom. Melalui indikator kepercayaan diri ini menunjukkan bahwa kemandirian belajar mahasiswa cukup terarah dengan baik dengan penggunaan media google classroom serta melalui kombinasi paduan pembelajaran tatap muka dan online (Hybrid Learning).

Indikator disiplin memperoleh nilai ratarata 83,5 dengan interpretasi sangat kuat, berdasarkan wawancara dan pengamatan pada mahasiswa diperoleh informasi bahwa 
meskipun Pandemi COVID-19 adalah fenomena alam yang memaksa pembelajaran mahasiswa berubah dalam waktu singkat, namun media Google Classroom serta Hybrid Learning cukup dapat membuat mahasiswa beradaptasi terutama mengikuti petunjuk soal, petunjuk tugas dan petunjuk diskusi yang dijelaskan pada Google Classroom, disamping itu pula mahasiswa cukup dapat mengikuti regulasi ketika mereka diharuskan menyerahkan hardcopy tugas dan bertemu pada tatap muka yang ditentukan waktunya, begitu pula ketika menyerahkan softcopy tugas maupun diskusi sesuai tenggat waktu yang diberikan. Hal ini sejalan dengan hasil penelitian Rosdiana, Sukawati dan Firmansyah (2020:39) menyimpulkan bahwa Google Classroom terbukti dapat meningkatkan sikap kedisiplinan mahasiswa dalam pengumpulan tugas-tugas khususnya tugas mata kuliah dengan respn yang sangat positif serta pengumpulan tugas tepat waktu.

Indikator Inisiatif memperoleh nilai ratarata 81, 44 dan Indikator Tanggung Jawab memperoleh nilai rata-rata 85,94 dengan interpretasi sangat kuat, berdasarkan wawancara dan pengamatan pada mahasiswa diperoleh informasi bahwa mahasiswa juga berinisiatif belajar menggunakan media Google Classroom melalui internet, membaca bahan-bahan untuk memperkaya pemahaman materi serta inisiatif dan bertanggung jawab untuk menyusun jadwal mengerjakan tugas, berdiskusi serta belajar mencari bahan dan sumber-sumber yang relevan sehingga kedua indikator ini juga berperan penting untuk menilai kemandirian belajar mahasiswa.

Indikator Motivasi memperoleh nilai ratarata 85,25 dengan interpretasi sangat kuat, berdasarkan wawancara dan pengamatan pada mahasiswa diperoleh informasi bahwa mahasiswa termotivasi dengan media Google Classroom yang dimanfaatkan sebagai media pembelajaran online, selain itu di masa Pandemi COVID-19, alternatif media pembelajaran ini cukup mudah diakses dan digunakan, selain itu pula dengan Hybrid Learning, mahasiswa membuka diri untuk beradaptasi menggunakan sistem pembelajaran gabungan berupa tatap muka dan online, hal ini sejalan dengan penelitian oleh Sulihin B. Sjukur (2013) berjudul " Pengaruh Blended Learning Terhadap Motivasi Belajar dan Hasil Belajar Siswa Tingkat SMK" , Hasil penelitian Sulihin B. Sjukur menunjukkan bahwa terdapat perbedaan motivasi belajar siswa menggunakan Blended Learning dibandingkan siswa yang diajarkan pembelajaran konvensional, kemudian ada peningkatan motivasi siswa akibat penerapan blended learning/Hybrid Learning.

Berdasarkan rata-rata keseluruhan indikator kemandirian belajar adalah 83,59. Dari hasil tersebut dapat diinterpretasikan berdasarkan rentang skala kriteria interpretasi skor tingkat capaian responden, maka interpretasi kemandirian belajar mahasiswa Penjas menggunakan media Google Classroom Melalui Hybrid Learning pada Pembelajaran Profesi Pendidikan di masa Pandemi COVID-19 adalah sangat kuat. Kemandirian belajar mahasiswa selain diperoleh dari data angket, wawancara dan pengamatan juga diperkuat dengan hasil post-test mahasiswa yang terdata mengalami kenaikan dibandingkan nilai pre-test sebagaimana terlihat pada gambar grafik berikut ini:

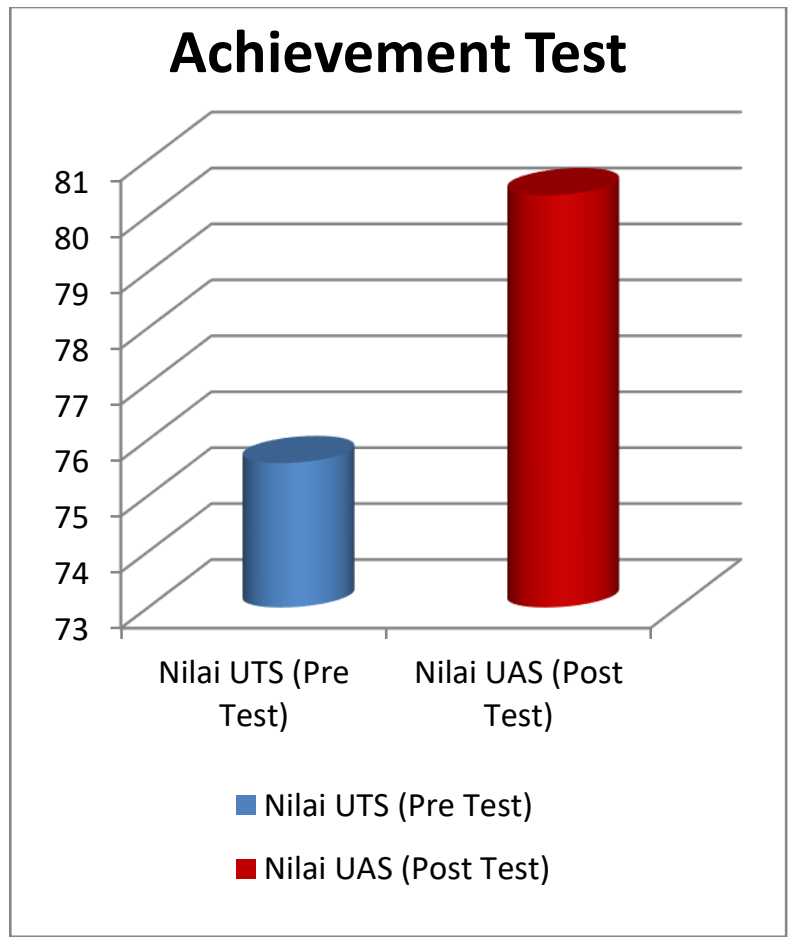

Gambar 2: Tes Pencapaian Belajar

Berdasarkan gambar diatas, cukup memperkuat bahwa diperoleh hasil tes cukup baik pada hasil tes akhir mahasiswa, meskipun keadaan Pandemi COVID-19 menyebabkan banyak kekhawatiran mahasiswa dan pengajar untuk dapat bertahan melaksanakan proses pembelajaran ditengah ketidaksiapan teknologi dan kemampuan dalam penggunaan teknologi, namun hal ini membuktikan bahwa penggunaan media dan pembelajaran Hybrid Learning dapat 
menjadi solusi untuk mempertahankan serta meningkatkan kemandirian belajar mahasiswa Penjas, meskipun pada umumnya mahasiswa Penjas merupakan mahasiswa yang sulit beradaptasi dengan pembelajaran Hybrid Learning disebabkan banyaknya mata kuliah praktek yang lebih menarik dibandingkan pembelajaran teori seperti mata kuliah Profesi Pendidikan, namun hasil akhir tes cukup baik begitupun hasil data angket dan wawancara.

\section{PENUTUP}

Disimpulkan bahwa dari kelima indikator kemandirian belajar memiliki rata-rata nilai dengan interpretasi sangat kuat yaitu: percaya diri $(81,82)$, disiplin $(83,5)$, inisiatif $(81,44)$, Tanggung Jawab $(85,94)$, Motivasi $(85,25)$, sehingga rata-rata keseluruhan indikator kemandirian belajar adalah 83,59. Dari hasil tersebut dapat diinterpretasikan berdasarkan rentang skala kriteria interpretasi skor tingkat capaian responden, maka interpretasi kemandirian belajar mahasiswa Penjas menggunakan media Google Classroom Melalui Hybrid Learning pada Pembelajaran Profesi Pendidikan di masa Pandemi COVID-19 adalah secara umum sangat kuat.

Berdasarkan hasil penelitian ini maka peneliti memberikan beberapa saran kepada mahasiswa untuk perlu selalu menanamkan nilai-nilai kemandirian belajar dalam diri, hal ini penting dilakukan sehingga mahasiswa selalu siap dalam keadaan apapun baik secara mental dan fisik dalam menghadapi kegiatan dan perubahan proses pembelajaran terutama pada masa Pandemi COVID-19, selain itu pula perlu bagi mahasiswa untuk mengedepankan dan mengikuti regulasi keamanan dan kesiagaan dalam menjaga kesehatan dan mengikuti prosedur kesehatan untuk pencegahan COVID19. Mahasiswa juga perlu senantiasa mengasah keterampilan berselancar menggunakan internet dan aplikasi/media pembelajaran online seperti: Google Classroom, Zoom, Multimedia, Macromedia Flash, Youtube, Skype, Moodle, dll. Begitupun harapan kepada peneliti selanjutnya, peneliti menyarankan untuk ke depan dapat diteliti terkait penggunaanpenggunaan ragam E-Learning baik tatap muka maupun online serta penggunaan aplikasi dan media online sebagai alternatif pembelajaran jarak jauh terutama pada masa Pandemi ini serta kelemahan dan keunggulan penggunaan media/aplikasi tersebut dalam pembelajaran minim persiapan.

\section{DAFTAR PUSTAKA}

Bender, W., \& Waller, L. (2014). Google Apps. In Cool Tech Tools for Lower Tech Teachers: 20 Tactics for Every Classroom. https://doi.org/10.4135/9781483387840.n 16

Bersin, J. (2004). The Blended Learning Book: Best Practices, Proven Methodologies, and Lessons Learned. San Fransisco: Pfeiffer Publishing

Brookfield, S.D. (2000) Understanding and Facilitating Adult Learning. San Fransisco: Josey-bass Publisher.

Masrun. (1986). Studi Mengenai Kemandirian Pada Penduduk di Tiga Suku, Laporan Penelitian Kantor Menteri Negara dan Lingkungan Hidup. Yogyakarta: Fakultas Psikologi UGM.

Mujiman, Haris. (2008). Belajar Mandiri. Surakarta: UNS Press.

Riduwan. (2006). Belajar Mudah Penelitian untuk Guru-Karyawan dan Peneliti Pemula.Bandung:Alfabeta Rosdakarya.

Rosdiana, Lilis A., Sukawati, S., \&Firmansyah, D. (2020). Meningkatkan Kedisiplinan Melalui Google Classroom dalam Mata Kuliah Bahasa Indonesia. Semantik Journal Vol 9, No. 1. Online ISSN: 2596506 Print ISSN: 2252-4657. Available at: $\quad$ http://ejournal.stkipsiliwangi.ac.id/index.php/se $\underline{\text { mantik/article/view/1669/0 . Diakses }}$ pada tanggal 25 Juni 2020

Sjukur, Sulihin B. Pengaruh blended learning terhadap motivasi belajar dan hasil belajar siswa di tingkat SMK. Jurnal Pendidikan Vokasi, [S.1.], v. 2, n. 3, jan. 2013. ISSN 2476-9401. Available at: <https://journal.uny.ac.id/index.php/jpv/a rticle/view/1043. Date accessed: 22 aug. 2020.

doi:https://doi.org/10.21831/jpv.v2i3.104 3.

Sudarwo, R., Yusuf, Y., \& Anfas, A. (2018). Pengaruh Sarana Belajar Dan Motivasi Belajar Terhadap Kemandirian Belajar Mahasiswa (Studi Empirical Pada Mahasiswa Beasiswa Bidikmisi UPBJJUT Ternate). Jurnal Pendidikan, 19(2), 68-83.

https://doi.org/10.33830/jp.v19i2.152.201 8 
Jurnal Teknologi Pendidikan, Vol. 13, No. 2, Oktober 2020, e-ISSN: 2407-7437

Suryaningsih, E. (2017). Pengaruh Media Animasi Dan Simulasi Serta Kemandirian Belajar Terhadap Hasil Belajar Biologi Siswa SMAN 25 Kabupaten Tangerang. Jurnal Pendidikan, 18(1), 115.

https://doi.org/10.33830/jp.v18i1.277.201 $\underline{7}$

Widiara, I. K. 2018. Blended Learning sebagai Alternatif Pembelajaran di Era Digital. Purwadita, vol. 2, no. 2, 2018, pp. 50-56. 